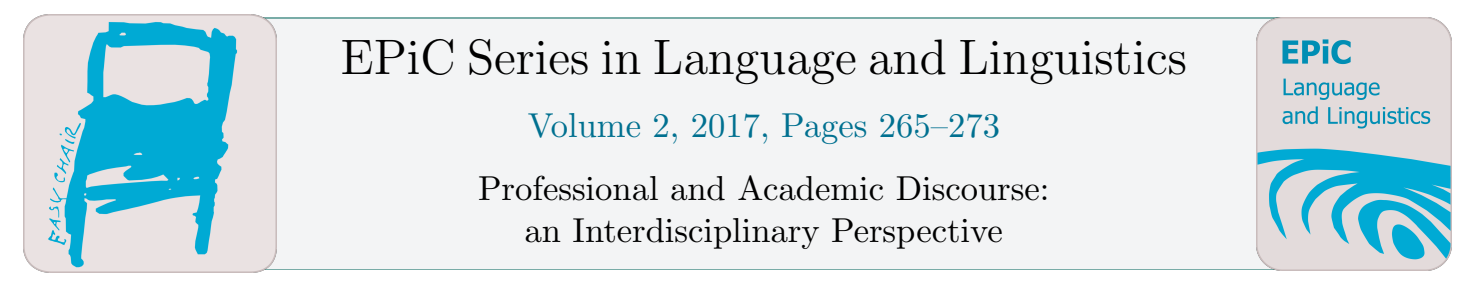

\title{
Cultural Values and Interpersonality in Spanish and British University Websites
}

\author{
Francisco Miguel Ivorra \\ University of Valencia, Valencia, Spain \\ francisco.ivorra@uv.es
}

\begin{abstract}
The aim of this paper is to study the impact of Spaniards' and Britons' index of individualistic cultural values (Hofstede, 1991) on the type of engagement markers (Hyland and Tse, 2004) used in Peninsular-Spanish and British university websites along with the English translated version of the former. The cultural dimension of individualism is related to the way in which individuals from a particular culture define their own identity and their relationship with other people. As regards engagement markers, these are used to establish a social interaction in the online encounter held between universities and prospective students who may wish to study in these institutions. Following an observational and a quantitative analysis, the findings reveal important statistical differences in the three corpora analysed and show that culture and engagement markers may be considered intertwined concepts. The results obtained may be a valuable source of information for Peninsular-Spanish universities as they may help them not only to translate into English the Spanish version of their websites but also to adapt the appropriate engagement markers taking into account the British cultural framework.
\end{abstract}

\section{Introduction}

From an anthropological perspective the term 'culture' has received many definitions throughout the decades. The first definition of the term correlated with "that complex whole which includes knowledge, belief, art, morals, law, custom, and any other capabilities and habits acquired by man as a member of society" (Tylor, 1975: 21). 'Culture' has also been defined as a "shared system of attitudes, beliefs, values and behaviour" (Gibson, 2000: 7) as well as "the software of the mind or collective mental programming" (Hofstede, 1991: 4). It is crystal clear then that all the above definitions correlate the term 'culture' with the idea of "shared values" (Hofstede, 1991; Singh and Pereira, 2005; Guillén-Nieto, 2009). In other words, 'culture' refers to the way in which, in a particular group, people are trained from a very early age to internalise the behaviour and attitudes of the group. In fact, these patterns of thinking that people have internalised since their childhood make 
up their 'cultural framework' which, according to Guillén-Nieto (2005: 9), can be interpreted as "the perceptual lens through which an individual filters the information provided by his/her physical senses and comes to grips with the world".

In this study we focus on the five-value cultural dimension paradigm designed by the Dutch engineer and social psychologist Geert Hofstede (2003/1991) (power distance, individualism, masculinity, uncertainty avoidance and time orientation). In particular, we base our analysis on the cultural dimension of 'individualism'. This makes reference to the way in which the members of a particular society understand the concept of the 'self' and their relationship with other people. This cultural dimension may be explained as a continuum along which cultural groups may show a tendency to either individualistic or collectivist cultural orientations. While in individualistic cultures "people are expected to look after themselves or their immediate family", in collectivist cultures "people from birth onwards are integrated into strong, cohesive in-groups, which throughout people's lifetime continue to protect them in exchange for unquestioning loyalty”(Hofstede, 1991: 51).

During the 60's and the 70's, Geert Hofstede carried out a research with employees working for the U.S. American multinational technology and consulting company IBM. By using questionnaires, he collected data to get first-hand information on the index of individualistic cultural values held by the staff of this company, who came from different nationalities and cultures. As such, he designed a scale from 0 to 100 to measure the individualism index of each country, being 0 the most collectivist culture and 100 the most individualistic one. As regards Spain and the UK, Hofstede's findings revealed that Spaniards scored 51 points whereas the UK scored 89 points on that index. These scores make Spain to be considered a moderately individualistic culture and the UK a highly individualistic one.

It is important to highlight that Hofstede's five-value dimension paradigm has attracted criticism during the last decades as it has been considered old-fashioned (e.g. the study was carried out more than three decades ago), capable of promoting overgeneralizations as well as leading to the creation of stereotypes (Loukianenko-Wolfe, 2008). Nonetheless, some scholars (Clark, 1990; Simon, 1999; Guillén-Nieto, 2009; Ivorra-Pérez, 2014, 2015) hold the opinion that Hofstede has provided the most comprehensive and influential study based on empirical quantitative data of how values in the workplace are influenced by culture at a collective level. In other words, we cannot overlook the fact that there could always be differences within a cultural group that deviate from the norm.

Regarding the concept of 'metadiscourse', this makes reference to the way in which "writers project themselves into their discourse to signal their attitude towards both the content and the audience of the text” (Hyland and Tse, 2004: 156). In our research, we draw on one type of interactional metadiscourse included in Hyland and Tse's model: engagement markers. In relation to our study, these are used to establish a social interaction in the online encounter that is held between universities and prospective students from abroad who may wish to study in these educational institutions.

Many linguists have done research on the use of interactional metadiscourse strategies in different professional and academic genres belonging to different countries and cultures following Hyland and Tse's model (2004) (Valero-Garcés, 1996; Dafouz-Milne, 2006, 2008; Shokouki and Talati, 2009; Mur-Dueñas, 2010, Suau-Jiménez, 2010). Despite the importance of the aforementioned studies from a cross-cultural perspective, we think a deeper explanation seems to be needed to shed some light on how cultural values may influence the divergent interactional metadiscourse strategies found in different countries and cultures. Indeed, our research is embedded in the discipline called 'Intercultural Pragmatics', which draws its attention to the description and contrast of the culturespecific pragmalinguistic conventions ruling speech acts, social interaction and discourse strategies cross-culturally as an objection to the alleged universalism of certain linguistic theories based on an Anglo-Saxon context (e.g. Grice's Cooperative Principle, 1975; Brown and Levinson's Linguistic Politeness Principle, 1987). 
During the last decades some studies have focused on analysing the influence of cultural values on language-specific behaviour (Loukianenko-Wolfe, 2008; Prykarpatska, 2008; Guillén-Nieto, 2009; García-Yeste, 2013; Ivorra-Pérez, 2014, 2015). As far as the influence of culture on interactional metadiscourse strategies is concerned, it is worth mentioning Guillén-Nieto's (2013) study on the business letter of introduction or Ivorra-Perez's $(2014,2015)$ research on business websites.

\section{Objectives and Hypotheses}

Taking as a point of departure Hofstede's individualism index for Spain and the UK, the objective of this research is to examine the influence of Spaniards' and Britons' individualism index on the type of engagement markers used in Peninsular-Spanish and British university websites along with the English translated version of the former. Following this objective, this paper hypothesises that the differing cultural orientations Spaniards and Britons hold with respect to the cultural dimension of 'individualism' may promote different writing cultures in professional discourse. Hence, Spaniards and Britons are likely to have different perspectives and interpretations as to the way engagement markers are produced and interpreted in a digital professional genre like the university website.

The main research questions we attempt to answer are: (a) Do university websites conform to the same type of engagement markers in Spain and the UK?, (b) Do the English translated version of Peninsular-Spanish university websites include the same type of engagement markers as the ones used on the Spanish version? and (c) What is the nature of any difference found and what factors influence these differences?

\section{Methodology and Corpus Selection}

A sample of 60 university websites (30 from Spain and 30 from the UK) has been randomly selected together with the English translated version of the Peninsular-Spanish corpus. More particularly, we have decided to analyse the section called "Reasons to study at the university" or "Why studying at ...? since, in our view, this can be considered one of the most important sections of university websites to attract students from all over the world.

As for the analysis, the first stage has consisted in observing and classifying the most relevant types of engagement markers used on the aforementioned section of the websites selected for the corpora. Secondly, a quantitative analysis has been carried out with the help of the computer program TextWorks 1.0 (Gil-Salom, et al. 2004), in order to count the absolute and relative frequency of each type of engagement marker on all the university websites analysed. Then, the results have been submitted to statistical analysis through the Chi-square test of homogeneity in a contingency table by means of SPSS Statistics Software 18. In this respect, if the statistical difference has been equal to or below $\mathrm{p}<.05$, the result has been interpreted as significant and if it has been below $\mathrm{p}<.01$, it has been considered highly significant. It should be taken into account that the information provided on this particular section of the websites is not equivalent in terms of quantity since a difference in lexical density in the corpora has been found. Therefore, the absolute frequency of each engagement marker has also been computed per 1,000 words, which is a conventional way of standardizing results of corpora of different sizes. 


\section{Results and Discussion}

The main types of engagement markers found in our corpora are: (a) second-person pronouns and second-person references in the verb ending; (b) rhetorical questions; (c) verbs in imperative form; and (d) references to a third person in discourse. It is important to observe that the latter is not included in Hyland and Tse's model (2004). Nevertheless, due its high frequency in the corpora analysed, we have deemed it relevant to include it as another type of engagement marker.

\begin{tabular}{|l|l|l|l|l|l|}
\hline $\begin{array}{l}\text { Interactional } \\
\text { metadiscourse } \\
\text { strategies }\end{array}$ & \multicolumn{2}{|l|}{$\begin{array}{l}\text { Peninsular-Spanish } \\
\text { university websites }\end{array}$} & \multicolumn{2}{|c|}{$\begin{array}{l}\text { British } \\
\text { university websites }\end{array}$} & Chi-square test \\
\hline Engagement markers & $\begin{array}{l}\text { AF } \\
\mathrm{n}=15,482 \\
\text { words }\end{array}$ & $\begin{array}{l}\text { RF } \\
\text { x } \\
1,000 \\
\text { words })\end{array}$ & $\begin{array}{l}\text { AF } \\
\mathrm{n}=39,419 \\
\text { words }\end{array}$ & $\begin{array}{l}\text { RF } \\
\text { (x } \\
1,000 \\
\text { words })\end{array}$ & Spanish-British \\
\hline $\begin{array}{l}\text { Second-person } \\
\text { pronouns/Second- } \\
\text { person references in } \\
\text { the verb ending }\end{array}$ & 364 & $23.5 \%$ & 975 & $24.7 \%$ & $843.588(.000)^{* * *}$ \\
\hline Rhetorical questions & 19 & $1.2 \%$ & 55 & $1.4 \%$ & $18.186(.000)^{* * *}$ \\
\hline Imperatives & 61 & $3.9 \%$ & 160 & $4 \%$ & $49.858(.000)^{* * *}$ \\
\hline $\begin{array}{l}\text { References to a third } \\
\text { person in discourse }\end{array}$ & 109 & $7.04 \%$ & 254 & $6.4 \%$ & $70.764(.000)^{* * *}$ \\
\hline
\end{tabular}

Table 1. Frequency of engagement markers in Peninsular-Spanish and British university websites

If we take a glance at table 1 above in which we compare the frequency of engagement markers in Peninsular-Spanish and British websites, higher frequencies of second-person pronouns, rhetorical questions and verbs in imperative form are included in the British corpus, all of them with highly significant statistical differences with respect to the Peninsular-Spanish one. The preference for these types of explicit engagement markers might have its explanation in the high index of individualistic cultural values that the British hold (89 scores). Indeed, there are many researchers (Caillat and Mueller, 1996; De Mooij, 2000; Usunier and Lee, 2005) who agree with the idea that individualistic cultures favor a more explicit communicative style in which saying what you really think is regarded as a virtue.

In the case of Peninsular-Spanish websites, however, references to a third person in discourse are found with much higher frequencies than imperatives or rhetorical questions. This type of engagement marker could be considered more implicit than the other three types analysed. This would explain why Spain, as a moderately individualistic culture (51 scores), reinforces a more implicit style of communication (De Mooij, 2004). Indeed, Peninsular-Spanish speakers place more value on the 'positive face' when interacting with other interlocutors. In other words, for the Peninsular-Spanish culture, concepts such as cooperation and involvement with other interlocutors are considered paramount. Explicit engagement markers like second-person pronouns, verbs in imperative form or rhetorical questions could be interpreted by Spaniards as if they were threatening that involvement.

Despite this, we cannot overlook the fact that the British websites also include references to a third person in discourse, even more than their Peninsular-Spanish counterparts. In the same vein, the latter also incorporate higher frequencies of second-person pronouns or second-person references in the verb ending. This inevitably leads us to partially refute Hofstede's individualistic cultural indexes for Spain and the UK, and back up the thesis put forward by the linguist Nan Leaptrott (1996). 
According to this linguist (1996: 107-109, 322), the foundations of the English culture may be considered extremely individual-oriented. However, there is a strong overlap of tribal values from both the Roman and Holy Roman empires that left England a moderately tribal society. In fact, the English derive their identity from their family and its place in society. On the contrary, Scotland and Wales, as a result of having escaped from the Roman Empire, seem to favor high individualistic values, in which to speak one's mind is highly valued and considered to be a sign of honesty.

By the same token, Spain can be situated in a middle position between individualism and collectivism. In this respect, Leaptrott (1996: 107-109) prefers to categorize Spain as a "high tribal culture”, as Spain's history has been dominated by Roman, Islamic, and Catholic rules. Therefore, this society is tribal and places value on the power and the welfare of the family group. The above reasons make us think that Spain and England, like most Western European cultures, value individualism. Nevertheless, their values and orientations towards this cultural dimension differ slightly. As such, on a continuum from collectivism to individualism, "Spaniards are believed to hold high tribal values, whereas Britons, particularly Scots and the Welsh, hold cultural values that vary from a moderately tribal orientation to a moderately individualistic one” (Guillén-Nieto, 2005: 118). Let us proceed to illustrate some examples taken from the corpora analysed. The first four extracts are taken from the British corpus and the last four from the Peninsular-Spanish one:

Choose to study at $\mathrm{X}^{1}$ and you will be investing in education that will help you build a successful future. You'll experience the very best in teaching and research [...] Come and join us [...] Why choose the University of $X$ ?

As a X student you will contribute to this exciting process of knowledge creation [...] Integral to your learning is the development of skills that will serve you well [...] The year in industry initiative organizes relevant work placement for young people to spend [...].

As an X undergraduate you'll be part of one or more departments, depending on the course you're studying [...] Every student at $\mathrm{X}$ is a member of a college [...] Your college will be your home for much of your time at $\mathrm{X}[\ldots]$ The relatively small number of students at each college allows for close and supportive personal attention to be given to your induction, academic development and welfare [...].

We offer more than 65 subjects within our 30 undergraduate courses -take a look at the course outlines in the courses profiles [...] [...] most of our courses cover the subject area broadly to start with before allowing you to choose from a range of specialisms. This means you can explore the subject and your strengths and interests fully before you decide which area to focus on.

La oferta académica se complementa con un amplio catálogo de servicios, que incluye un sinfín de actividades complementarias, como la Extensión Universitaria, done el estudiante puede tomar parte de aulas y cursos de temática variada [...] [...] La Universidad de X cuenta con un amplio Servicio de Deportes que facilita al estudiante la práctica de todo tipo de actividades [...] Para facilitar la estancia a los estudiantes internacionales la Universidad de X dispone de un Servicio de Alojamiento a través del cual el alumno puede encontrar apoyo [...].

La Universidad de $\mathrm{X}$ es, sin duda, una de las mejores opciones para estudiar una carrera universitaria [...] Es una universidad cercana al alumnado, al que ofrece múltiples herramientas de emprendimiento, para facilitarle su inserción laboral [...] Te animamos a formar parte de nuestra comunidad universitaria [...].

Ofrecemos un trato personalizado, procurando siempre conocer las necesidades y asistencia que cada alumno necesita [...] La X te prepara, te ayuda y te acompaña en tu inserción en la vida laboral [...].

El universitario encuentra múltiples oportunidades para ampliar sus aptitudes personales e intelectuales [...] Estas oportunidades de formación integral convierten a los universitarios en protagonistas del desarrollo económico [...].

\footnotetext{
${ }^{1}$ For data protection rights, the name of universities has not been included in this document
} 
When examining the Peninsular-Spanish university websites and their English translated version in table 2 below, it can be observed that the frequency of engagement markers is more or less similar with no significant statistical differences. This implies that there seems to be a literal translation from Spanish into English. Yet, the number of instances in the use of second-person references is much higher in the Peninsular-Spanish corpus than in its English translated version counterpart. That is why we find highly significant statistical differences.

\begin{tabular}{|l|l|l|l|l|l|}
\hline $\begin{array}{l}\text { Interactional } \\
\text { metadiscourse } \\
\text { strategies }\end{array}$ & \multicolumn{2}{|c|}{$\begin{array}{l}\text { Peninsular-Spanish } \\
\text { university websites }\end{array}$} & \multicolumn{2}{c|}{$\begin{array}{l}\text { English } \\
\text { translated version }\end{array}$} & Chi-square test \\
\hline Engagement markers & $\begin{array}{l}\mathrm{AF} \\
\mathrm{n}=15,482 \\
\text { words }\end{array}$ & $\begin{array}{l}\mathrm{RF} \\
\mathrm{x} \\
1,000 \\
\text { words })\end{array}$ & $\begin{array}{l}\mathrm{AF} \\
\mathrm{n}=13,086 \\
\text { words }\end{array}$ & $\begin{array}{l}\mathrm{RF} \\
\mathrm{x} \\
1,000 \\
\text { words })\end{array}$ & $\begin{array}{l}\text { Spanish-English } \\
\text { translation }\end{array}$ \\
\hline $\begin{array}{l}\text { Second-person } \\
\text { pronouns/Second- } \\
\text { person references in } \\
\text { the verb ending }\end{array}$ & 364 & $23.5 \%$ & 236 & $18 \%$ & $39.010(.000)^{* * *}$ \\
\hline Rhetorical questions & 19 & $1.2 \%$ & 19 & $1.4 \%$ & $.000(1.000)$ \\
\hline Imperatives & 61 & $3.9 \%$ & 54 & $4.1 \%$ & $.452(.501)$ \\
\hline $\begin{array}{l}\text { References to a third } \\
\text { person in discourse }\end{array}$ & 109 & $7.04 \%$ & 86 & $6.5 \%$ & $3.006(.083)$ \\
\hline
\end{tabular}

Table 2. Frequency of engagement markers in Peninsular-Spanish websites and their English translated version

The findings above show that, generally speaking, the English translated version of the PeninsularSpanish university websites needs the incorporation of more instances of second-person pronouns, rhetorical questions and verbs in imperative form to adapt their websites to the British culture so as to convince English students about the significance of studying at Spanish universities. To support our results, we reproduce two examples of Peninsular-Spanish websites taken from the corpus analysed and their translated version in English:

La X es, sin duda, una Universidad atractiva para los estudiantes no sólo por la alta calidad de la oferta docente [...] Te animamos a formar parte de nuestra comunidad universitaria [...] Consulta cómo se accede a nuestras enseñanzas y las actividades que se proponen para la orientación y acogida de los futures y nuevos estudiantes, las condiciones y facilidades para hacer una estancia temporal en nuestra universidad o para estudiar como estudiante extranjero y los servicios de los que disfrutan nuestros estudiantes en el día a día de la vida universitaria.

Clearly, students are attracted to the X, not only by the high quality course offerings [...] Come and join our university community [...] Find out how to apply to our courses and about the orientation and reception activities for prospective and new students, the conditions and facilities for studying temporarily at the $\mathrm{X}$ or for taking a course as an international student, and the services that our students can access in daily university life.

La Universidad de X desarrolla una importante labor de investigación [...] Gracias a esta actividad, de la que tú puedes ser partícipe, pretende incentivar [...] La X te ofrece la posibilidad de realizar prácticas en empresas [...] Las prácticas en empresas tienen como objetivo permitir a los alumnos aplicar los conocimientos adquiridos [...] La Dirección General de Empleo de la X tiene entre sus objetivos potenciar y reforzar la formación de carácter teórico que se imparte en las aulas, facilitando la incorporación y desarrollo profesional del alumno en el mercado laboral. [...] La Universidad de $\mathrm{X}$ pone a disposición de los alumnos que presenten algún tipo de discapacidad [...]. 
The University of $\mathrm{X}$ develops considerable effort of research [...] Through this activity, in which you can be involved, it aims at encouraging [...] The X offers you the possibility of internships in companies [...] Practical work in companies is intended to help students apply the knowledge gained [...] The General Directorate for Employment of the X has among its objectives the enhancement and strengthening of training offered in classrooms, facilitating the incorporation and professional development of the student in the labour market. [...] The University of X offers a hospitable service and Psycho-pedagogical attention and advice to students with some type of disability [...].

\section{Conclusions}

The results derived from this study show that the frequency of engagement markers established in the taxonomy of Hyland and Tse (2004) is especially relevant in the UK corpus. In contrast, Spanish universities prefer to include in their websites depersonalization strategies like references to a third person in discourse. Nonetheless, the numerous instances of references to a third person in discourse in the British corpus as well as the use of second-person references in the Peninsular-Spanish one, make us feel inclined to partially refute Hofstede's individualism index on Spain and the UK, at least as far as this professional genre is concerned. As such, our findings would be much better interpreted in the light that Spain may be regarded as a highly tribal culture where the presence of individualistic and collectivist cultural values can be found. This could explain why not only the inclusion of references to a third person in discourse are worth considering but also second-person references as interactional markers to get potential British students be interested in their universities. Even though an implicit interactive style through the use of reference to a third person in discourse prevails, explicit engagement markers like second-person pronouns or verbs ending in second-person references are also found.

Concerning the UK, we could say that, in spite of the fact that the British hold deep individualistic roots, they also favour moderately tribal cultural values. This would mean that despite an explicit communicative style prevails to interact with prospective students from abroad by means of secondperson pronouns, imperatives or rhetorical questions; an implicit style of communication through the use of references to a third person can also be appreciated. Even though the English translated version of Peninsular-Spanish websites incorporates second-person pronouns, more rhetorical questions and verbs in imperative form should be included to fully adapt these websites to the British culture where they would like to promote their educational institutions.

Despite the importance of the results obtained in our research, we are concerned with its own limitations too. We must consider that for the purposes of this study the English translated version appearing in the Peninsular-Spanish corpus has been analysed bearing in mind the British culture as a point of reference. However, it should be pointed out that this English version does not only address British students but also students from other countries. In spite of the fact that English is the lingua franca in the international scenario, a translation from Spanish into English does not seem to be enough to address all the potential students who may wish to study in Spain. As people from different countries have different cultural frameworks to orient themselves, it would be a good idea for universities to create different versions in English of their websites with the incorporation of the appropriate interactional metadiscourse strategies to fully adapt their websites to the target culture where they would like to promote their educational institutions.

In our view, further investigation seems necessary to observe how other cultural values proposed in Hofstede's cultural dimensions are reflected not only in engagement markers but also in other types of interactional metadiscourse strategies. An in-depth analysis of whether interactional metadiscourse strategies used in this digital professional genre may be actually due to cultural values or maybe to the constraints imposed by the particular genre deserves special attention. Apart from references to a third 
person in discourse, other types of implicit engagement markers may be worth exploring in future research (e.g. passive and impersonal sentences, nominalizations, etc.). The correlation between the individualism cultural dimension and politeness should also be addressed. Research into professional genres belonging to other countries would also be worth taking into consideration so that we can have more empirical data on the influence of cultural values on professional discourse. Last, but not least, surveys and questionnaires should be used to get more data about the way in which the British process and interpret the interactional metadiscourse strategies contained in the English translated version of the Peninsular-Spanish university websites. In this way, we could carry out not only a linguistic study but also a sociolinguistic one.

\section{References}

Brown, P. and Levinson, S. (1987): Politeness. Some Universals in Language Use. Cambridge: Cambridge UP.

Caillat, Z. and Mueller B. (1996): "The Influence of Culture on American and British Advertising. An Exploratory Comparison of Beer Advertising.” Journal of Advertising Research 36 (3): 79-87.

Clark, T. (1990): "International Marketing and National Character: A Review and Proposal for an Integrative Theory.” Journal of Marketing 50: 66-79.

Dafouz-Milne, E. (2006): "Estudio de los marcadores interpersonales en el comentario periodístico: estrategias para la identificación autor-lector en el texto.” Resla 19: 67-82. , (2008): "The Pragmatic Roles of Textual and Interpersonal Metadiscourse Markers in the Construction and Attainment of Persuasion: A Cross-Linguistic Studyof Newspaper Discourse.” Journal of Pragmatics 40: 95-113.

De Mooij, M. (2000): "Mapping Cultural Values for Global Marketing and Advertising." In International Advertising, Realities and Myths, edited by John Philips, 214-218. Sage Publications Inc. , (2004): Consumer Behaviour and Culture: Consequences for Global Marketing and Advertising. Thousands Oaks, CA: Sage Publications

García-Yeste, M.A. (2013): "Press Advertisement for Food in Spain: Cultural Orientations and Communicative Style.” Ibérica 26:195-216.

Gibson, R. (2000): Intercultural Business Communication. Oxford: Oxford UP.

Gil-Salom, L., Soler-Monreal, C., Stewart, K, and Candela-Coderch J. (2004). TextWorks (CD Rom). Valencia. Universidad Politécnica de Valencia.

Grice, P. (1975): “Logic and Conversation.” In Syntax and Semantics: Speech Acts, Vol. 3, edited by Peter Cole and Jerry Morgan, 45-47. New York: Academic.

Guillén Nieto, V. (2005): "The Invisible Face of Culture: Why do Spanish Toy Manufacturers Believe the British are Most Peculiar in Business?” In Thistles, A Homage to Brian Hughes, edited by José Mateo and Francisco Yus, 95-127. Departamento de Filología Inglesa: Universidad de Alicante. , (2009): “Crossing Disciplines in Intercultural Communication Research.” In Intercultural Business Communication and Simulation and Gaming Methodology, edited by Victoria Guillén, Carmen Marimón and Chelo Vargas, 29-64. Peter Lang: Bern.

, (2013): "Intercultural Business Pragmatics: The Case of the Business Letter of Introduction.” In Research Trends in Intercultural Pragmatics, edited by Ivan Kecskes and Jesús Romero Trillo, 395-420. Boston/Berlin: Walter de Gruyter, Inc.

Hofstede, G. (2003/1991): Cultures and Organizations. Software of the Mind. London: Benjamins.

Hyland, K. and Tse, P. (2004): "Metadiscourse in Academic Writing: A Reappraisal." Applied Linguistics 25 (2): 156-77. 
Ivorra-Pérez, F.M. (2014): "Cultural Values and their Correlation with Interactional Metadiscourse Strategies.” Atlantis 36 (2): 73-95.

, (2015): "The Impact of Cultural Dimensions on the Engagement Markers of Spanish, British and US Toy Selling Websites.” In Studies in Pragmatics 14. A Multidisciplinary Approach to Service Encounters, edited by María de la O Hernández-López and Lucía FernándezAmaya, 141-163. Leiden/Boston: Brill.

Leaptrott, N. (1996): Rules of the Game: Global Business Protocol. Ohio: International Thomson Publishing.

Loukianenko-Wolfe, M. (2008): "Different Culture-Different Discourses. Rhetorical Patterns of Business Letters by English and Russian Speakers." In Contrastive Rhetoric. Reaching to Intercultural Rhetoric, edited by Ulla Connor, Ed Nagelhout and William V. Rozycki, 87-121. Amsterdam/Philadelphia: John Benjamins.

Mur-Dueñas, P. (2010): “Attitude Markers in Business Management Research Articles. A CrossCultural Corpus-Driven Approach.” International Journal of Applied Linguistics 20 (1): 50-72.

Prykarpatska, I. (2008): "Why are you so Late?”: Cross-Cultural Pragmatic Study of Complaints in American English and Ukrainian.” Revista Alicantina de Estudios Ingleses 21: 87-102.

Shokouhi, H. and Talati, A. (2009): "Metadiscourse Functions in English and Persian Sociology Articles: A Study in Contrastive Rhetoric.” Poznan Studies in Contemporary Linguistics 45 (4): 54968.

Simon, J. (1999): “A Cross-Cultural Analysis of Web Site Design: An Empirical Study of Global Web Users.” Paper presented at the Seventh Cross-Cultural Consumer and Business Studies Research Conference. Cancun: Mexico.

Singh, N. and Pereira, A. (2005): The Culturally Customized Web Site. Customizing Web Sites for the Global Marketplace. Burlington, MA: Elsevier.

Suau-Jiménez, F. (2010): La traducción especializada (en inglés y español en géneros de economía y empresa). Madrid: Arcos.

Tylor, E. B. (1975): “La ciencia de la cultura.” In El concepto de cultura. Textos fundamentales, edited by J.S. Khan, 29-46. Barcelona: Anagrama.

Usunier, J. and Lee, J. (2005): Marketing across Cultures (4th Edition). Harlow: Prentice Hall.

Valero-Garcés, C. (1996): "Contrastive ESP Rhetoric. Metatext in Spanish-English Economic Texts.” English for Specific Purposes 15 (4): 279-94. 